\title{
Sepsis Et Causa Empiema Dekstra Et Causa Community Acquired Pneumonia Dengan Komorbid Diabetes Melitus
}

\section{Sepsis Et Causa Empiema Dekstra Et Causa Community Acquired Pneumonia with Komorbid Diabetes Melitus}

\author{
Eka Irawan, Irvan Medison, Fenty \\ Anggraini, Dessy Mizart. \\ Departemen Pulmonologi dan Kedokteran Respirasi Fakultas \\ Kedokteran Universitas Andalas/RSUP DR. M. Djamil \\ Padang, Indonesia
}

KATA KUNCI KEYWORDS

ABSTRAK
Sepsis; Pneumonia; Diabetes Melitus

Sepsis; Pneumonia; Diabetes Melitus

Sepsis adalah respon inflamasi sistemik terhadap infeksi yang berat. Sepsis merupakan penyebab utama morbiditas dan mortalitas terutama pada usia lanjut, imunocompromised, penderita dengan kondisi kritis. Pneumonia merupakan lesi infeksi primer tersering pada pasien sepsis. Sepsis berat dapat terjadi akibat infeksi yang berhubungan dengan pelayanan kesehatan dan dapat pula diperoleh dari komunitas (Community Acquired Pneumonia). Penelitian melaporkan bahwa 5-10\% pasien pneumonia yang dirawat di rumah sakit berkembang menjadi empiema dan angka kematian meningkat secara bermakna dibandingkan pasien pneumonia tanpa empiema. Kejadian infeksi lebih sering terjadi pada pasien dengan diabetes akibat munculnya lingkungan hiperglikemik yang meningkatkan virulensi patogen, menyebabkan terjadinya disfungsi kemotaksis dan aktifitas fagositik, serta kerusakan fungsi neutrofil. Infeksi paru pada diabetes melitus ditandai dengan perubahan pada pertahanan imun host, di seluruh tubuh, dan khususnya secara lokal di paru maupun pada fungsi epitel pernapasan dan motilitas silia. Tatalaksana sepsis pada kasus ini dengan terapi cairan yang adekuat, pemberian antibiotik kombinasi dan segera mengevakuasi pus dari rongga pleura dengan pemasangan chest tube, dan tatalaksana komorbid diabetes melitus dengan protokol drip insulin untuk kontrol glukosa serum. 
ABSTRACT Sepsis is a systemic inflammatory response to severe infections. Sepsis is a major cause of morbidity and mortality, especially in the elderly, immunocompromised, sufferers with critical conditions. Pneumonia is the most common primary infection lesion in sepsis patients. Severe sepsis can occur due to infections related to health services and can also be obtained from the community (Community Acquired Pneumonia). Research reports that $5-10 \%$ of pneumonia patients treated in hospitals develop empyema and the mortality rate significantly increases compared to pneumonia patients without empyema. Infection is more common in patients with diabetes due to the emergence of a hyperglycemic environment that increases virulence of pathogens, causes chemotaxic dysfunction and phagocytic activity, and damage to neutrophil function. Pulmonary infection in diabetes mellitus is characterized by changes in host immune defense, throughout the body, and especially locally in the lungs as well as in respiratory epithelial function and ciliary motility. Management of sepsis in this case with adequate fluid therapy, administration of combined antibiotics and promptly evacuating pus from the pleural cavity by chest tube placement, and management of diabetes mellitus comorbidities with the insulin drip protocol for glucose serum control.

\section{PENDAHULUAN}

Sepsis adalah respon inflamasi sistemik terhadap infeksi yang berat, sepsis merupakan sindrom yang disebabkan oleh infeksi yang ditentukan oleh dua atau lebih gambaran peradangan sistemik yaitu febris atau hipotermia, leukositosis atau leukopenia, takikardi dan takipnea. Sepsis merupakan penyebab utama morbiditas dan mortalitas terutama pada usia lanjut, imunocompromised, penderita dengan kondisi kritis. Pneumonia merupakan lesi infeksi primer tersering pada pasien sepsis. Sepsis berat dapat terjadi akibat infeksi yang berhubungan dengan pelayanan kesehatan dapat pula diperoleh dari komunitas (Community Acquired Pneumonia) (Sameraro et al., 2012).

Pneumonia komunitas atau community acquired pneumonia (CAP) adalah pneumonia yang terjadi di masyarakat yang merupakan salah satu penyakit infeksi yang banyak terjadi dan penyebab kematian dan kesakitan terbanyak di dunia. Pneumonia komunitas menduduki urutan ke-3 dari 30 penyebab kematian di dunia. Angka kematian pneumonia komunitas pada rawat jalan $2 \%$, rawat inap $5-20 \%$ dan di ruang intensif $>50 \%$.

\footnotetext{
Correspondence:

Eka Irawan, Departemen Pulmonologi dan Kedokteran Respirasi Fakultas Kedokteran Universitas Andalas/RSUP DR. M. Djamil Padang, Indonesia Email: ekairawan23.ei@gmail.com
} 
Pneumonia komunitas menjadi suatu penyakit yang sangat mengancam jiwa terutama pada pasien lanjut usia dan pasien dengan penyakit komorbid seperti Penyakit Paru Obstruktif Kronik (PPOK), diabetes melitus, gagal jantung, penyakit arteri koroner, keganasan, gangguan fungsi ginjal dan penyakit hati kronik (Purwitasari et al.,2013).

Empiema saat ini masih menjadi masalah penting dalam bidang penyakit paru. Angka kematian penyakit ini berkisar antara 5 hingga 30 persen dengan insidens bervariasi berdasar kondisi komorbid. Penelitian lain melaporkan bahwa $5-10 \%$ pasien pneumonia yang dirawat di rumah sakit berkembang menjadi empiema dan angka kematian meningkat secara bermakna dibandingkan pasien pneumonia tanpa empiema. Angka kematian juga akan meningkat hingga $40 \%$ pada immunocompromised (Sahn, 2007). Infeksi paru pada diabetes mellitus ditandai dengan perubahan pada pertahanan imun host, di seluruh tubuh, dan khususnya secara lokal di paru maupun pada fungsi epitel pernapasan dan motilitas silia. Keadaan ini ditandai dengan gambaran klinis yang serius, durasi yang lebih lama, komplikasi yang lebih sering, dan peningkatan mortalitas (Sahn, 2007).

Sepsis merupakan masalah kesehatan umum di seluruh dunia dengan kejadian tahunan sekitar 200 hingga 300 kasus per 100.000 penduduk. Sepsis memiliki tingkat kematian sekitar $20 \%$ dan bahkan sampai $40 \%$ pada pasien dengan syok sepsis. Penatalaksanaan komprehensif dan adekuat mencakup eliminasi patogen penyebab infeksi, eliminasi sumber infeksi dengan tindakan drainase atau bedah bila diperlukan, terapi anti mikroba yang sesuai, resusitasi bila terjadi kegagalan organ, vasopresor dan inotropik (Sameraro et al., 2012; Mervyn et al., 2016). Pentingnya masalah sepsis membuat penulis tertarik untuk membahas kasus tentang sepsis terutama menegakkan diagnosis sepsis sesuai dengan kompetensi penulis. Diharapkan dengan adanya laporan kasus ini menambah pengetahuan dan bisa tatalaksana sepsis dengan baik sehingga angka kesakitan dan kematian yang ditimbulkan bisa berkurang.

\section{KASUS}

Pasien laki-laki usia 60 tahun, datang ke IGD RSUP Dr. M. Djamil dengan keluhan utama: Sesak napas meningkat sejak 1 hari sebelum masuk rumah sakit, sesak tidak menciut meningkat dengan aktivitas, batuk sejak 5 hari sebelum masuk rumah sakit, dahak warna kekuningan, batuk darah tidak ada, nyeri dada tidak ada, riwayat demam 1 minggu yang lalu, tinggi, tidak menggigil dan bersifat hilang timbul, keringat malam tidak ada. Riwayat sering terbangun malam hari karena sering BAK ada, BAB tidak ada keluhan, sering haus dan sering lapar ada. Riwayat minum OAT tidak ada, riwayat diabetes melitus ada, sudah dikenal, normoweight, tidak terkontrol. Pekerjaan pasien pegawai diperusahaan swasta, kebiasaan merokok sejak usia 15 tahun, 20 batang/hari, selama 40 tahun berhenti 5 tahun ini (bekas perokok, Index Brikmant berat). Pemeriksaan fisik keadaan umum tampak sakit berat kesadaran somnolen, TD 120/70mmhg, nadi $120 \mathrm{x} /$ menit, napas $30 \mathrm{x} /$ menit, suhu $38,3^{\circ} \mathrm{C}, \mathrm{SpO}_{2}$ $99 \%$, TB $170 \mathrm{~cm}$, BB $60 \mathrm{Kg}$, BMI 20,76 (Normoweight) Pemeriksaan fisik paru didapatkan Inspeksi asimetris kanan 
cembung dari kiri (statis). Pergerakan kanan tertinggal dari kiri (dinamis). Palpasi fremitus kanan lemah dari kiri. Perkusi Kanan=atas-RIC V=sonor, RIC V-kebawah=Pekak, Kiri=sonor. Auskultasi, Kanan atas- RIC V Suara nafas bronkovesikuler rhonki ada, wheezing tidak ada RIC V kebawah suara nafas melemah sampai menghilang, Kiri=Suara nafas bronkovesikuler rhonki ada, wheezing tidak ada. Jantung Inspeksi: iktus jantung tidak terlihat, Palpasi Iktus teraba 1 jari lateral LMCS RIC VI. Perkusi Batas jantung atas RIC II, batas jantung kanan sukar dinilai, batas jantung kiri 1 jari lateral LMCS RIC VI. Auskultasi bunyi jantung irama teratur, murmur tidak ada, gallop tidak ada.
Ekstremitas Akral hangat, edema tidak ada. Pemeriksaan laboratorium didapatkan hemoglobin 12,6gr/dl, leukosit $20630 / \mathrm{mm}^{3}$, hematokrit $41 \%$, trombosit $351.000 / \mathrm{mm}^{3}$, gula darah sewaktu $205 \mathrm{mg} / \mathrm{dl}$, ureum $52 \mathrm{mg} / \mathrm{dl}$, kreatinin $1,1 \mathrm{mg} / \mathrm{dl}$. Elektrolit natrium $138 \mathrm{mmol} / 1$, kalium 4,3mmol/1, kalsium $8,5 \mathrm{mg} / \mathrm{dl}$, Klorida $84 \mathrm{mmol} /$. Total protein $6,6 \mathrm{~g} / \mathrm{dl}$, albumin $3,4 \mathrm{~g} / \mathrm{dl}$, globulin $3,2 \mathrm{~g} / \mathrm{dl}, \quad$ bilirubin total $0,9 \mathrm{mg} / \mathrm{dl}$, bilirubin direk $0.5 \mathrm{mg} / \mathrm{dl}$, bilirubin indirek $0,4 \mathrm{mg} / \mathrm{dl}$, sgot $40 \mathrm{u} / \mathrm{l}$, sgpt $34 \mathrm{u} / \mathrm{l}$, LDH $220 \mathrm{u} / \mathrm{l}$. Analisa gas darah $\mathrm{PH} 7,538 \mathrm{PCO}_{2} 18,1 \mathrm{mmHg}, \mathrm{PO}_{2}$ $154,9 \mathrm{mmHg}, \mathrm{HCO}-15,6 \mathrm{mmol} / \mathrm{l}, \mathrm{BE}-$ $4,4 \mathrm{mmol} / \mathrm{l}$, saturasi $99,1 \%$ dengan terpasang NRM 8 1/mnt.

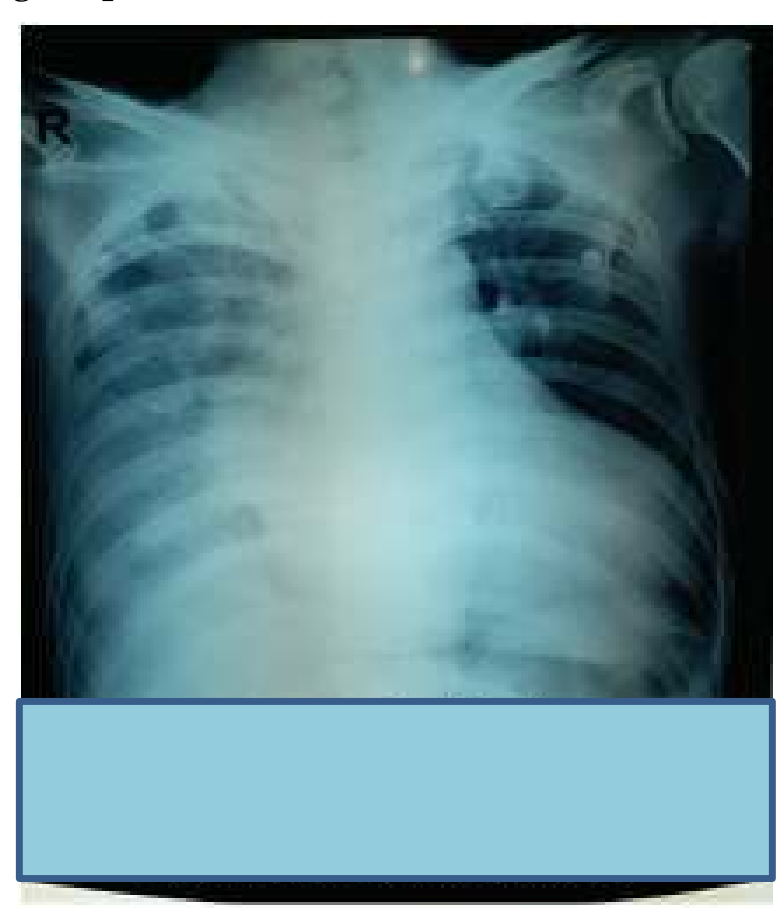

Gambar 1. Rontgen Toraks Pasien

Pemeriksaan foto toraks jantung ada, apex tertanam, Kesan Efusi didapatkan gambaran perselubungan homogen di hemithoraks kanan, jantung terdorong kekiri, trakea tidak terdorong, infiltrat kedua lapangan paru dominan di lobus atas, CTR tidak dapat dinilai segmen aorta normal, segmen pulmonal normal, pinggang pleura dekstra + Pneumonia + Kardiomegali. Dilakukan proof dan pungsi cairan pleura di LAA dekstra keluar pus, $10 \mathrm{cc}$, dilanjutkan pemasangan thoraks tube no 28 keluar pus \pm 1500 cc. 


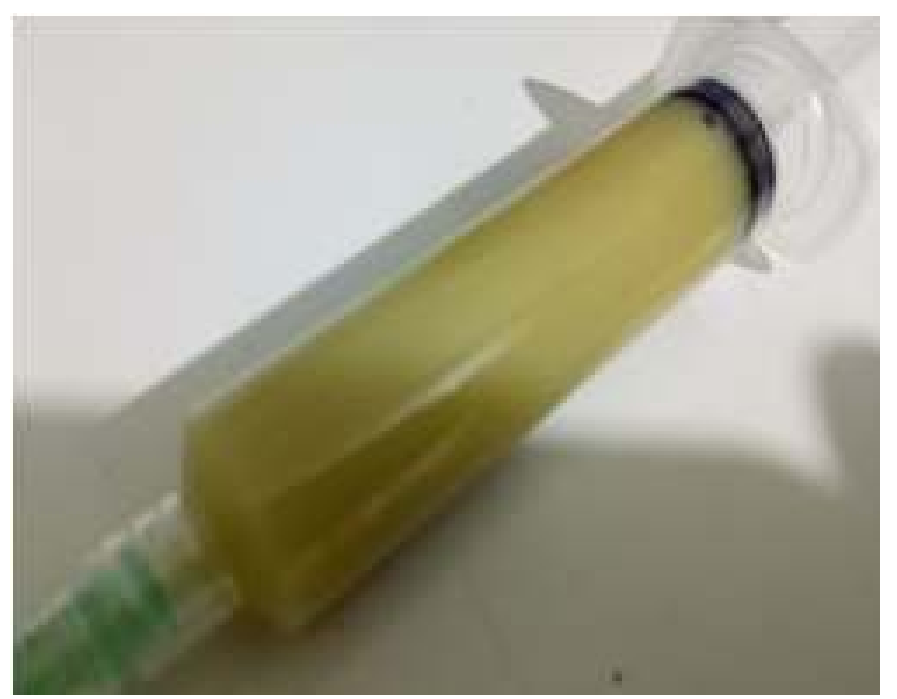

Gambar 2. Cairan Pleura Pasien

Pasien di diagnosis dengan Sepsis et causa empiema dekstra et causa Community Acquired Pneumonia terpasang WSD hari I DM tipe II sudah dikenal, tidak terkontrol, normoweight. Tata Laksana: Rawat HCU Paru IVFD $\mathrm{NaCl}$ 0,9\% 6 jam/kolf. Oksigen sesuai kebutuhan RM 8 1/mnt, pasang Thorak Tube. Injeksi Meropenem 3x1 gram (skin test dulu) Infus Levofloksasin $1 \times 750 \mathrm{mg}$ (skin test dulu) Infus Metronidazol 3x500mg, Drip Insulin sesuai protokol, diet DM 1900 kkal via NGT. Pasang monitor Kontrol intensif. Pasang kateter urin: hitung balance cairan. Cek Prokalsitonin Kirim Kultur pus, Kirim kultur darah Kirim kultur Sputum dan sensitivitas kuman banal Cek BTA I, II Cek TCM Cek AGD ulang. Setelah 3 hari tatalaksana terapi di HCU pasien perbaikan, terapi antibiotik tetap dilanjutkan sampai menunggu hasil kultur sputum, kultur pus dan kultur darah keluar.

\section{PEMBAHASAN}

Telah dirawat seorang pasien laki-laki 60 tahun dengan diagnosis Sepsis et causa empiema dekstra et causa Community Acquired
Pneumonia, DM tipe II sudah dikenal, tidak terkontrol, normoweight, diagnosis ditegakkan berdasarkan anamnesis, pemeriksaan fisik, skor qSOFA, pemeriksaanpenunjang laboratorium ditemukan leukosito sis, rontgen thorak ada infiltrat, efusi pleura dan telah dilakukan proof dan pungsi cairan pleura keluar pus dan dilanjutkan pemasangan thorak tube. Sepsis didefinisikan sebagai disfungsi organ yang mengancam jiwa dan disebabkan oleh suatu disregulasi respon host terhadap infeksi. Definisi baru ini menekankan tentang peran penting dari respon host terhadap infeksi, potensi letalitas yang dianggap berlebihan terhadap suatu infeksi, dan pentingnya pengenalan dini untuk kondisi ini (Sameraro et al., 2012; Mervyn et al., 2016). Berdasarkan penelitian epidemiologi, Martin, dkk, menunjukkan bahwa di Amerika Serikat tahun 1979 sampai tahun 2000 dilaporkan 10.319.418 kasus sepsis atau meningkat sekitar $13,7 \%$ per tahun dimana 164.072 kasus pada tahun 1979. Usia rata-rata pasien wanita 62,1 tahun dan pria 56,9 tahun (Fadhil, 2016). Pada kasus ini hampir sama dengan penelitian laki-laki usia 60 tahun. 
Kejadian sepsis di Indonesia berkisar antara 1,5-3,72\% pada beberapa rumah sakit rujukan di Indonesia seperti RS Cipto Mangunkusumo, sedangkan angka kematian berkisar antara 37,09-80\%. Sepsis dapat disebabkan oleh bakteri gram negatif 70\% (Pseudomonas, aeruginosa, Klebsiella, Enterobakter, E. Coli, Proteus), gram positif 20-40\% (stafilokokus aureus, streptokokus, pneumokokus). Pada praktek seharihari kultur yang sering ditemukan adalah pseudomonas, disusul oleh stafilokokus dan pneumokokus (Fadhil et al., 2016; Chen et al., 2007). Sepsis berat dapat terjadi akibat infeksi yang berhubungan dengan layanan kesehatan dapat pula diperoleh dari komunitas community acquired pneumonia (CAP) Di negara industri, infeksi saluran nafas merupakan penyebab sepsis terbanyak sekitar 35\% sampai 50\%. Penelitian International Multicentre Prevalence on Sepsis (IMPRESS) diruang gawat darurat dan ICU rumahsakit di Eropa, Amerika Serikat dan Asia mendapatkan bahwa $35 \%$ sepsis disebabkan oleh infeksi saluran nafas, $21 \%$ oleh infeksi saluran kemih 16,5\% dari infeksi intra abdomen 2,3\% infeksi yang berhubungan dengan pemakaian kateter intravena, 1,3\% dari pemakaian alat-alat, 0,8\% dari infeksi susunan saraf pusat dan $11,3 \%$ dari penyebab lainnya seperti selulitis dan infeksi intraartikular (NCEC, 2014). Sepsis pada kasus ini juga disebabkan adanya infeksi pneumonia yang akhirnya menjadi empiema.

Endotoksin yang dilepaskan oleh mikroba akan menyebabkan proses inflamasi yang melibatkan berbagai mediator inflamasi yaitu sitokin, neutrofil, komplemen, NO, dan berbagai mediator lain. Produk yang berperan penting terhadap sepsis adalah lipopolisakarida (LPS). LPS merangsang peradangan jaringan, demam dan syok pada penderita yang terinfeksi. Struktur lipid A dalam LPS bertanggung jawab terhadap reaksi dalam tubuh penderita. LPS endotoksin gram negatif dinyatakan sebagai penyebab sepsis terbanyak. Dia dapat langsung mengaktifkan sistem imun seluler dan humoral yang dapat menimbulkan septikemia. LPS sendiri tidak mempunyai sifat toksik tetapi merangsang pengeluaran mediator inflamasi yang bertanggung jawab terhadap sepsis. Makrofag mengeluarkan polipeptida yang disebut factor nekrosis tumor (Tumor Necrosis Factor/TNF) dan Interleukin 1(IL-1), IL6 dan IL-8 yang merupakan mediator kunci dan sering meningkat sangat tinggi pada penderita immunocompromise (IC) yang mengalami sepsis (Christopher et al., 2015). Pada kasus ini pasien penderita immunocompromise diabetes melitus. Proses inflamasi pada sepsis merupakan proses homeostasis dimana terjadi keseimbangan antara inflamasi dan antiinflamasi. Bila proses inflamasi melebihi kemampuan homeostasis, maka terjadi proses inflamasi yang maladaptif sehingga terjadi berbagai proses inflamasi yang destruktif, kemudian menimbulkan gangguan pada tingkat seluler pada berbagai organ. Proses berlanjut dengan terjadi disfungsi endotel, vasodilatasi akibat pengaruh NO yang menyebabkan mal distribusi volume darah sehingga terjadi hipoperfusi jaringan dan syok. Pengaruh mediator juga menyebabkan disfungsi miokard sehingga terjadi penurunan curah jantung (Christopher et al., 2015; Jefrey et al., 2016). 
$\begin{array}{lrr}\text { Lanjutan } & \text { proses } & \text { inflamasi } \\ \text { menyebabkan } & \text { gangguan } & \text { fungsi } \\ \text { berbagai organ } & \text { yang dikenal sebagai } \\ \text { disfungsi/gagal } & \text { organ multipel } \\ \text { (Multiple Organ Failure (MOF). Proses }\end{array}$ MOF merupakan kerusakan pada tingkat seluler (termasuk difungsi endotel), gangguan perfusi jaringan, iskemia reperfusi, dan mikrotrombus. Berbagai faktor lain yang diperkirakan turut berperan adalah terdapatnya faktor humoral dalam sirkulasi (myocardial depressant substance), malnutrisi kalori protein, translokasi toksin bakteri, gangguan pada eritrosit, dan efek samping dari terapi yang diberikan (Mossie et al., 2013). Sintesis NO mempengaruhi tonus pembuluh darah sehingga berperan dalam pengaturan tekanan darah. Produksi NO melalui Inducible nitrit oxide Synthase (iNOS) memiliki peranan penting dalam patogenesis syok septik. Sel penjamu merespons lipopolisakarida dan sitokin dengan mengeluarkan berbagai sitokin proinflamasi dan terjadi peningkatan ekspresi iNOS yang menghasilkan kuantitas besar NO. Produksi NO pada paru dan hepar menyebabkan hipotensi sistemik dan depresi miokard yang merupakan ciri khas syok sepsis (Christopher et al., 2015; Jefrey et al., 2016).

Respon kardiovaskular awal meliputi menurunnya resistensi pembuluh darah sistemik dan depresi fungsi ventrikel. Resistensi sistemik terjadi sebagai respon terhadap zat yang dilepaskan oleh kuman, sitokin, mediator seperti Nitrit Oksida (NO) dan menurunnya kepekaan reseptor katekolamin perifer (Down Regulation of Peripheral Catecholamine Receptors). Sebab dari depresi fungsi ventrikel tidak diketahui namun berbagai mediator radang dan edema jaringan ikut terlibat
(Yanti et al., 2003). Jika respon kardiovaskular awal ini tidak terkompensasi maka terjadi hipoferfusi jaringan seluruh tubuh. Resusitasi cairan yang agresif dapat memperbaiki curah jantung dan tekanan darah sistemik sehingga menghasilkan pola hemodinamik yang khas dari syok sepsis yaitu cardiac index yang tinggi dan resistensi sistemik yang rendah. Respon terhadap muatan volum (volume loading) pada pasien sepsis yang selamat adalah dilatasi ventrikel. Pasien yang meninggal memperlihatkan sedikit dari perubahan dari curah jantung. Walaupun demikian sekalipun ada perbaikan dalam hemodinamik sentral, abnormalitas di aliran darah regional dan mikrosirkulasi sering menetap (Christoper et al., 2015).

Manifestasi klinis sepsis sangat bervariasi, tergantung pada lokasi asal infeksi, organisme penyebab, pola disfungsi organ, status kesehatan pasien dan interval sebelum pasien mendapat terapi. Hiperventilasi sering merupakan tanda awal terjadinya sepsis, disorientasi, bingung dan manifestasi ensefalopati lainnya juga sering terjadi diawal sepsis terutama pada usia tua dengan gangguan neurologis sebelumnya, hal ini sesuai dengan kasus pasien masuk IGD dengan kondisi somnolen, hiperventilasi dengan frekuensi nafas $30 \mathrm{kali} /$ menit. Gejala gastrointestinal seperti mual, muntah, diare dan ileus, gejala kolestasis dengan peningkatan bilirubin serum dan alkali fosfatase juga merupakan terjadinya sepsis (Mossie et al., 2013; Munford et al., 2008). Disfungsi organ dapat diidentifikasi sebagai suatu perubahan akut pada sepsis-related organ failure assessment (SOFA) score yaitu skor SOFA total sebesar $\geq 2$ poin sebagai akibat dari infeksi (Mervyn et al., 2016; Hari et al., 
2016). Skor dasar SOFA dapat dianggap sebagai nol pada pasien yang tidak diketahui memiliki disfungsi organ sebelumnya. Skor SOFA sebesar $\geq 2$ menandakan risiko mortalitas keseluruhan sebesar kurang lebih $10 \%$ pada populasi umum pasien di rumah sakit dengan suspek infeksi. Bahkan pasien dengan disfungsi derajat ringan dapat mengalami perburukan lebih lanjut, hal ini menunjukkan pentingnya kondisi ini dan perlunya intervensi yang cepat dan tepat (Mervyn et al., 2016; Hari et al., 2016). Pasien suspek infeksi yang kemungkinan besar memerlukan rawatan di ICU yang lebih lama atau meninggal di rumah sakit dapat diidentifikasi secara klinis dengan cepat dengan menggunakan qSOFA, yang meliputi perubahan status mental, tekanan darah sistolik $\leq 100 \mathrm{mmHg}$, atau frekuensi pernafasan $\geq 22 \mathrm{kali} /$ menit (Hari et al., 2016).

Pada pasien ini memenuhi 2 kriteria skor qSOFA diantaranya pada saat pasien masuk telah terjadi perubahan kesadaran yaitu somnolen, dengan frekuensi pernafasan 30 kali/menit. Walaupun qSOFA memiliki kekuatan yang lebih lemah dibandingkan dengan skor SOFA sebesar 2 atau lebih pada rawatan di ICU, metode ini tidak membutuhkan pemeriksaan laboratorium dan dapat dinilai secara cepat dan berulang-ulang. SSC menyarankan agar kriteria qSOFA digunakan oleh para klinisi untuk menginvestigasi lebih lanjut tentang disfungsi organ, untuk memulai atau meningkatkan terapi sesuai kebutuhan pasien, dan untuk mempertimbangkan perlu atau tidaknya pasien dirujuk ke pusat pelayanan penyakit kritis atau meningkatkan frekuensi pemantauan pasien.
Tata laksana dari sepsis
menggunakan protokol yang dikeluarkan oleh Society of Critical Care Medicine (SCCM) dan European Society of Critical Care Medicine (ESICM) yaitu "Surviving Sepsis Guidelines". Surviving Sepsis Guidelines pertama kali dipublikasi pada tahun 2004, dengan revisi pada tahun 2008 dan 2012. Pada bulan Januari 2017, revisi keempat dari Surviving Sepsis Guidelines dipresentasikan pada pertemuan tahunan SCCM dan dipublikasikan di Critical Care Medicine dan Intensive Care Medicine dimana didapatkan banyak perkembangan baru pada revisi yang terbaru (Backer et al., 2017). Komponen dasar dari penanganan sepsis dan syok septik adalah resusitasi awal, pada pasien diberikan terapi infus $\mathrm{NaCl}$ 0,9\% 6jam/kolf, vasopressor/inotropik, dukungan hemodinamik, pemberian antibiotik awal, terapi antibiotik kombinasi meropenem dan levofloksasin, kontrol sumber infeksi, diagnosis (kultur dan pemeriksaan radiologi), pada dilakukan pengiriman sampel kultur cairan pleura, tata laksana suportif (ventilasi, dialisis, transfusi) dan pencegahan infeksi (Samero et al., 2012).

Penanganan infeksi merupakan komponen penting dalam penanganan sepsis. Tingkat kematian akan meningkat dengan adanya penundaan penggunaan antimikroba. Untuk meningkatkan keefektifitas penggunaan antibiotik, penggunaan antibiotik berspektrum luas sebaiknya disertai dengan kultur dan identifikasi sumber penularan kuman (Shiferaw et al., 2016). Dan hal ini dilakukan sesegera mungkin. Protokol terbaru merekomendasikan bahwa penggunaan antibiotik harus diberikan maksimal dalam waktu 1 jam. Rekomendasi ini 
berdasarkan berbagai penelitian yang meunjukkan bahwa penundaan dalam penggunaan antibiotik berhubungan dengan peningkatan resiko kematian (Backer et al., 2017). Penggunaan vasopressor yang direkomendasikan adalah norepinefrin untuk mencapai target MAP $\geq 65 \mathrm{mmHg}$. Penggunaan cairan yang direkomendasikan adalah cairan kristaloid dengan dosis 30ml/kgBB dan diberikan dengan melakukan fluid challenge selama didapatkan peningkatan status hemodinamik berdasarkan variabel dinamis (perubahan tekanan nadi, variasi volum sekuncup) atau statik (tekanan nadi, laju nadi). Pada suatu penelitian yang dilakukan oleh Bernard et al., penggunaan drotrecogin a (Human Activated Protein C) menurunkan tingkat kematian pada pasien dengan sepsis. Protein C yang teraktivasi akan menghambat pembentukan thrombin dengan menginaktifasi factor Va, VIIIa dan akan menurunkan respon inflamasi (Bernard et al., 2001).

Empiema thoraks (ET) adalah akumulasi pus dirongga pleura dapat bersekat atau tidak bersekat. Semua efusi pleura yang berhubungan dengan pneumonia bakteri, abses paru atau bronkiektasis disebut efusi parapneumonia (EPP). Sedangkan dikatakan empiema apabila akumulasi pus di rongga pleura dimana pemeriksaan cairan pleura didapatkan berat jenis lebih dari 1.018, jumlah leukosit lebih dari 500sel $/ \mathrm{mm}^{3}$ atau protein lebih dari $2,5 \mathrm{~g} / \mathrm{dl}$, empiema bila hasil kultur cairan pleura positif atau leukosit lebih dari $15000 / \mathrm{mm}^{3}$ dan protein lebih dari 3,0g/dl (Light, 2011). Empiema saat ini masih menjadi masalah penting dalam bidang penyakit paru, insidens bervariasi berdasar kondisi komorbid. Penelitian lain melaporkan bahwa 5-10\% pasien pneumonia yang dirawat di rumah sakit berkembang menjadi empiema dan angka kematian meningkat secara bermakna dibandingkan pasien pneumonia tanpa empiema. Angka kematian juga akan meningkat hingga $40 \%$ pada immunocompromised. Walaupun terapi antibiotika berkembang pesat, drainase pleura memadai dan pembedahan dekortikasi tersedia, terapi ini belum dapat menurunkan angka kematian empiema. Pada 20-30\% pasien empiema, pemberian antibiotika dan drainase dengan perkutaneous chest tube gagal mengendalikan infeksi (Sahn et al., 2007). Pada kasus ini pasien empiema dengan immunocompromised diabetes melitus.

Sejak ditemukannya antibiotik, penyakit ini diperkirakan sudah jauh berkurang, namun meskipun demikian morbiditas maupun mortalitasnya masih cukup tinggi. Efusi parapneumonia (EPP) adalah penyebab utama Empiema toraks (ET), sekitar 20$60 \%$ pasien yang dirawat karena pneumonia akan menjadi efusi parapneumonia dan 5-10\% akan menjadi empiema toraks (Ahmed et al., 2010). Diagnosis pasti pneumonia ditegakkan jika pada foto toraks terdapat infiltrat/air bronchogram ditambah dengan beberapa gejala dibawah ini, batuk, perubahan karakteristik dahak/purulen, suhu tubuh $\geq 38^{\circ} \mathrm{C}$ (aksila)/riwayat demam, nyeri dada, sesak napas, pemeriksaan fisik: ditemukan tanda-tanda konsolidasi, suara napas bronkial dan ronki, Leukosit $\geq 10.000$ atau $<4500$ (PDPI, 2014). Diagnosis pneumonia pada pasien didasarkan atas ditemukan gejala akut dari anamnesa ada batuk berdahak kekuningan sudah dirasakan 
sejak 2 minggu, ada riwayat demam, sesak nafas, dari pemeriksaan fisik ditemukan adanya ronkhi, dari hasil laboratorium didapatkan peningkatan jumlah leukosit 20630/ $\mathrm{mm}^{3}$, dari rontgen thorak terlihat adanya infiltrat dikedua lapangan paru yang disertai dengan perselubungan homogen di hemitoraks kanan (PDPI, 2014).

Sebanyak $60-70 \%$ pasien dengan empiema memiliki penyakit dasar yang serius. Infeksi bakteri dan virus mempunyai peran dalam timbulnya empiema. Hampir 50\% pasien dengan empiema menunjukkan infeksi bakteri Streptococcus pneumonia, Staphylococcus aureus, bakteri gram negatif seperti Klebsiella pneumoniae dan bakteri anaerob. Infeksi virus dan mikoplasma hanya terjadi pada sebagian kecil pasien dengan empyema (Sahn, 2007). Penimbunan nanah pada rongga pleura disebabkan oleh invasi kuman piogenik kedalam pleura, dapat terjadi melalui beberapa cara diantaranya: secara langsung dari infiltrat pneumoni, penyebaran limpatika dari penyakit mediastinum, paru, dinding dada dan diafragma, penyebaran hematogen, inokulasi dari trauma tusuk, ruptur viscera abdomen ke rongga dada, perluasan infeksi subdiafragma ( $\mathrm{Yu}$ et al., 2011). Pneumonia dan abses paru adalah penyebab utama EPP yang akhirnya menyebabkan efusi pleura eksudatif. Penelitian yang dilakukan di Amerika mendapatkan hasil dari 1383 pasien dengan efusi parapneumonia $70 \%$ akan menjadi empiema toraks dan dari penelitian juga mendapatkan hasil 20-57\% dari 1 juta pasien di Amerika pasien yang dirawat inap dengan pneumonia mendapatkan komplikasi parapneumonia (Yu et al., 2011).

Pada pasien penyebab empiema adalah dari pneumonia hal ini sama dengan penelitian di Amerika. Acharya dan Shah melaporkan dari 40 pasien, $65 \%$ etiologinya tuberkulosis. Pada 21 paien $(63,6 \%)$ ternyata tidak ditemukan pertumbuhan kuman (steril). Tingginya kultur yang negatif berkorelasi dengan tingginya jumlah empiema tuberculosis (Munford et al., 2008). Infeksi bakteri dan virus mempunyai peran dalam timbulnya empiema. Hampir 50\% pasien dengan empiema menunjukkan infeksi bakteri Streptococcuspneumoniae, Staphylococcus aureus, bakteri gram negatif seperti Klebsiella pneumoniae dan bakteri anaerob. Infeksi virus dan mikoplasma hanya terjadi pada sebagian kecil pasien dengan empiema. Efusi parapneumonia terjadi pada pneumonia bakterialis yang berlokasi dekat permukaan pleura dan menyebabkan peradangan pleura yang meningkatkan produksi cairan pleura. Cairan pleura yang terbentuk mengandung jumlah leukosit dan konsentrasi Laktat Dehidrogenase (LDH). Empiema terjadi bila infeksi bakteri menembus kerongga pleura dan menyebabkan infeksi dalam rongga pleura. Cairan yang terbentuk pada empiema mengandung banyak leukosit dengan $\mathrm{pH}$ rendah dan kadar $\mathrm{LDH}$ tinggi (Sahn et al., 2007).

Sebagian besar kasus pneumonia disebabkan aspirasi mikroorganisme dari orofaring. Jika jumlah organisme lebih besar dari sistem imun tubuh maka akan terjadi pneumonia. Masa inkubasi berkisar antara beberapa hari sampai satu minggu. Pneumonia akan terjadi pada lobus tertentu di bagian perifer dan bila tidak mendapat terapi dengan baik akan menyebar sentripetal ke hilum. Terapi yang tidak adekuat dua sampai lima hari akan menyebabkan terjadi EPP. Efusi terbentuk karena peningkatan permeabilitas kapiler yang 
disebabkan aktivasi sel neutrofil yang akan melepaskan zat-zat yang menyebabkan peningkatan tekanan intertisial sehingga cairan pindah melalui mesotel ke rongga pleura (Light, 2011; Ahmed et al., 2010). Tatalaksana Empiema toraks adalah pemberian antibiotik dapat tunggal atau dikombinasi, torakosentesis, chest tube, fibrinolitik, torakoskopi, VATS dan dekortikasi. Tindakan yang akan dikerjakan tergantung pada sifat empiema saat diagnosis pertama dibuat, yaitu: Fase eksudasi, Fase Fibro purulen, Fase organisasi Tujuan utama tatalaksana ialah menghilangkan gejala dengan mengeluarkan cairan dari rongga pleura dan diikuti dengan terapi sesuai dengan penyakit dasarnya (Shrestha et al., 2011). Tatalaksana empiema pada kasus pasien ini yaitu dengan pemasangan chest tube dan terapi antibiotik kombinasi.

Infeksi pada pasien diabetes sangat berpengaruh terhadap pengendalian glukosa darah. Infeksi dapat memperburuk kendali glukosa darah, dan kadar glukosa darah yang tinggi meningkatkan kerentanan atau memperburuk infeksi. Kadar glukosa yang tidak terkendali perlu segera diturunkan, antara lain dengan menggunakan insulin, dan setelah infeksi teratasi dapat diberikan kembali pengobatan seperti semula (PERKENI, 2015). Kejadian infeksi lebih sering terjadi pada pasien dengan diabetes akibat munculnya lingkungan hiperglikemik yang meningkatkan virulensi patogen, menurunkan produksi interleukin, menyebabkan terjadinya disfungsi kemotaksis dan aktifitas fagositik, serta kerusakan fungsi neutrofil, glikosuria, dan dismotitilitas gastrointestinal dan saluran kemih.
Sarana untuk pemeriksaan penunjang harus lengkap seperti pemeriksaan kultur dan tes resistensi antibiotic (PERKENI, 2015).

Kasus ini pasien pneumonia dengan komorbid diabetes melitus kemudian mengalami sepsis dan meninggal dunia, pada penelitian dengan 645 subjek di Spanyol yang menemukan bahwa diabetes memiliki hubungan yang signifikan dengan mortalitas pada pasien pneumonia $(\mathrm{p}=0.002)$. Odds ratio dari kematian pasien pneumonia dengan diabetes ini ditemukan sebesar 2,005 (95\% CI:1,2273,277). Mortalitas pada pasien pneumonia dengan diabetes ini ditemukan berhubungan dengan adanya infiltrat multilobar, penyakit penyerta komplikasi dari diabetes melitus Glukosa darah yang direkomendasikan untuk pasien DM dengan penyakit kritis harus dikontrol pada kisaran $140-180 \mathrm{mg} / \mathrm{dL}$ dan tidak boleh melebihi $180 \mathrm{mg} /$ dl. Target yang lebih ketat seperti $110-140 \mathrm{mg} / \mathrm{dL}$, mungkin dapat diterapkan pada pasien-pasien tertentu, namun harus diperhatikan resiko terjadinya hipoglikemia. Pada hampir seluruh kondisi klinis di rawat inap, terapi insulin merupakan pilihan utama dalam kontrol glikemik. Pada pasien ICU, pemberian insulin secara drip intravena umumnya lebih dipilih. Di luar ICU, terapi insulin subkutan lebih direkomendasikan. Perlu diperhatikan resiko hiperglikemia pada perubahan terapi insulin drip intravena menjadi subkutan. Respon imun mengalami perubahan dan kerentanan terhadap infeksi yang meningkat pada pasien DM. Orang dengan DM memiliki kemungkinan lebih tinggi untuk terkena infeksi (PERKENI, 2015). 
Langkah-langkah kontrol glukosa darah pada pasien sepsis: Stabilisasi, Pasien dengan sepsis berat dan hiperglikemia di ICU: terapi insulin IV, Pasien yang menerima insulin IV juga menerima sumber glukosa kalori,Menggunakan validasi protokol untuk penyesuaian dosis insulin dan target glukosa darah hingga berkisar <150mg/dl, Memantau nilai glukosa darah setiap 1-2 jam sampai kadar nilai glukosa dan infus insulin stabil; dimonitor setiap 4 jam setelah itu. Tatalaksana diabetes melitus pada pasien ini telah sesuai konsensus DM-PERKENI 2015 untuk pasien DM dengan sepsis yaitu dengan protokol drip insulin dengan target glukosa darah $<150 \mathrm{mg} / \mathrm{dl}$.

\section{Simpulan dan Saran}

\section{Simpulan}

Sepsis adalah suatu sindroma klinik yang terjadi sebagai manifestasi proses inflamasi imunologi karena adanya respon tubuh yang berlebihan terhadap rangsangan produk mikroorganisme. Diagnosis Sepsis pada pasien ditegakkan dari anamnesis, gejala klinis infeksi dan qSOFA $\geq 2$ dan didukung pemeriksaan penunjang leukosit yang tinggi, dari rontgen gambaran infiltrat pneumonia, dan adanya fokus infeksi pus dari cairan pleura. Pneumonia merupakan lesi infeksi primer tersering pada pasien sepsis, sehingga harus ditatalaksana dengan baik, apalagi bila disertai dengan komorbid diabetes melitus perlu kontrol gula darah karena berkaitan dengan fungsi sel imunitas tubuh. Tatalaksana sepsis pada kasus ini dengan terapi cairan yang adekuat, pemberian antibiotik kombinasi dan segera mengevakuasi pus dari rongga pleura dengan pemasangan chest tube, dan tatalaksana komorbid diabetes melitus dengan protokol drip insulin untuk kontrol gula darah.

\section{Saran}

Dapat dilakukan penelitian maupun kajian ilmiah lebih lanjut dengan menggunakan sumber-sumber terbaru mengenai sepsis pada pneumonia dengan komorbid dan tata laksananya. Selain itu juga dapat diteliti kejadian sepsis pneumonia dengan prediksi luarannya.

\section{KEPUSTAKAAN}

Ahmed AE, Yacoub TE 2010. Empyema thoracis [review]. Clinical medicine insight: circulating, respiratory and pulmonary medicine.; 4: 1-8.

Backer D, Dorman T 2017. Surviving sepsis guidelines: a continuous move toward better care of patients with sepsis. JAMA.; 317(8): 807-8.

Bernard GR, Vincent JL, Laterre PF, LaRosa S, Dhainaut JP, Rodriguez AL, et al., 2001. Efficacy and safety of recombinant human activated protein c for severe sepsis. N Eng J Med; 344 (10): 699-709.

Chen K dan Pohan HT 2007. Penatalaksanaan Syok Septik dalam Sudoyo, Aru W. Setiyohadi, Bambang. Alwi, Idrus. Simadibrata K, Marcellus. Setiati, Siti. Buku Ajar Ilmu Penyakit Dalam Jilid I Edisi IV. Jakarta: Pusat Penerbitan Departemen Ilmu Penyakit Dalam FKUI. Pp: 187-9

Christopher W Seymour, Matthew R Rosengart 2015. Septic shock Advances in Diagnosis and Treatment. Jama.

Hari sankar, Philips 2016. Developing a New Definition and Assessing New Clinical Criteria for Septic Shock: For the Third International 
Consensus Definitions for Sepsis and Septic Shock (Sepsis-3). Jama.

Jeffrey E, Michael A 2016. Sepsis pathophysiologycal and clinical management. BMJ.

Light RW 2011. Parapneumonic Effusions and empyema. Bab 12. Pleural Disease. Fifth edition. Philadelphia, USA:179-210.

Mervyn Singer, clifford 2016. The Third International Consensus Definitions for Sepsis and Septic Shock. JAMA.

Mossie A 2013. Pathofisiology of septic. World Journal of Medicine and Medical Science.

Munford RS 2008. Severe Sepsis and Septic Shock. In A.Feluci,et al Harrison's Prinsiple of Internal 1 Medicine, $17^{\text {th }}$ ed. New york: Mc Graw-Hill Medica1, Ch .265.

Meissner M 2014. Update on Procalsitonin Measurement, Ann Lab Med: 34:263-273.

Mehta Y, Kochar G 2017. Sepsis and septic shock. Journal of Cardiac Critical Care TSS; 1(1): 3-5.

National Clinical Effectiveness Committee (NCEC) 2014. Sepsis Management National Clinical Guideline; No.6, An Roine Slainte Departement of Health, Ireland.

Purwitasari M, Burhan E, Soepandi PZ 2013. Peranan prokalsitonin pada pneumonia komunitas. Indones J Infect Dis ;33-41.

Perhimpunan Dokter Paru Indonesia (PDPI) 2014. Pneumonia Komuniti: Pedoman

Diagnosis
Penatalaksanaan di Indonesia. Perhimpun Dr Paru Indones; 6 .

Perkumpulan Endokrinologi Indonesia (PERKENI) 2015. Konsensus Pengelolaan dan Pencegahan Diabetes Mellitus tipe 2 di Indonesia. Jakarta: PB PERKENI; p.75-7.

Sameraro N, Ammollo CT, Sameraro F 2012. Sepsis, Thrombosis and Organ Disfunction, Thrombosis Research, Elseivers; 129: 290-5.

Sahn SA 2007. Diagnosis and management of parapneumonic effusions and empyema. Clin Infect Dis; 45:1480-6.

Shiferaw B, Bekele E, Kumar K, Boutin A, Frieri M 2016. The Role of Procalsitonin as A Biomarker in Sepsis: J.Infect Dis Epidemiol,vol 2(1);2: 006.

Shrestha K, Shah S, Tulung S, Karki b, Pokhrel DP 2011. Envolving experience in the management of emphyema thoracis. Kathmandu Univ Med J;33(1):5-7.

Yanti WS, Loehoeri S 2003. Profil pasien yang di Diagnosis Sepsis di RS Dr.Sardjito. Dalam Ilmu kedokteran Berkala, Yogyakarta,; 35:4:225-30.

$\mathrm{Yu}$ H 2011. Management of pleural effusion, empyema and lung abcess. Seminars in Interventional radiology; 28: 75-86.

Z Fadhil 2016.Definition, Incidence and Evolution of Sepsis \& Septic Shock. Open Acces. 